\title{
RaCe ANd Home OWNership: A Century-Long VieW
}

\author{
by
}

William J. Collins and Robert A. Margo

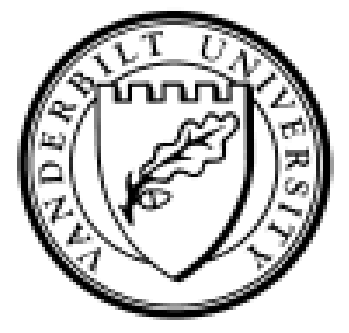

Working Paper No. 00-W12

May 2000

\section{DEPARTMENT OF ECONOMICS \\ VANDERBILT UNIVERSITY \\ NASHVILLE, TN 37235}

www.vanderbilt.edu/econ 


\title{
$\underline{\text { Race and Home Ownership: A Century-Long View }}$
}

\author{
by \\ William J. Collins \\ and \\ Robert A. Margo*
}

Revised, May 2000

*Department of Economics, Vanderbilt University, and National Bureau of Economic Research. Earlier versions of this paper were presented at the conference on "One Kind of Freedom" at Lehigh University, September 1999; the Stanford Conference on Race, November, 1999; and the ASSA meetings in Boston, January 2000. We are grateful to participants at the conferences, and to Stanley Engerman, Edward Glaeser, Timothy Guinnane, Paul Huck, Jens Ludwig, Shawn Kantor, Lawrence Katz, Peyton McCrary, Benjamin Polak, Ken Snowden, Eugene White, two anonymous referees, and workshop participants at the National Bureau of Economic Research, the University of Mississippi, and Yale University for helpful comments.

Corresponding Author: William Collins, Department of Economics, Box 35-B, Vanderbilt University, Nashville TN 37235, email: william.collins@ vanderbilt.edu, phone: 615-322-3428, fax: 615-343-8495. 
Running title: RACE AND HOME OWNERSHIP 


\title{
Race and Home Ownership: A Century-Long View
}

\begin{abstract}
This paper uses census IPUMS data to analyze trends in racial differences in home ownership and housing values and to examine the connection between residential segregation and the housing status of blacks relative to whites. A widening in the ownership gap between 1940 and 1960 is explained largely by the increasing concentration of blacks in central city areas whereas a narrowing in the ownership gap between 1960 and 1980 is explained only partly by changes in the relative characteristics of the black and white populations. Residential segregation did not widen the racial gap in home ownership rates in 1940 or 1980, but did widen the gap in housing values after 1940.
\end{abstract}


Labor economists and economic historians have paid considerable attention to the evolution of racial differences in labor market outcomes, especially income, during the twentieth century. ${ }^{1}$ However, long-run racial differences in other kinds of economic outcomes, including housing, remain relatively unexplored. ${ }^{2}$ This neglect is unfortunate because income is only one of several variables that we would expect to determine a group's economic well-being. For example, racial gaps in wealth were, and still are, much larger than racial differences in labor income, and housing equity is the single largest component of non-pension household wealth. ${ }^{3}$ Although correlated with earnings, housing quality per se is an important independent determinant of living standards.

This paper offers a century-long view of home ownership rates and half-century-long view of housing values in the United States, using samples of male household heads from the census Integrated Public Use Microdata Series (IPUMS). ${ }^{4}$ As far as we know, the census is the only source of consistent race-specific housing data that can be used to study racial housing gaps and their correlates over such a lengthy period of time. In addition to the data on home ownership and housing values, we also make use of census data on mortgage debt available in the IPUMS samples from the turn of the century and more recently (1980 and 1990), and data on levels of segregation in metropolitan areas calculated by Cutler, Glaeser, and Vigdor. ${ }^{5}$

Our major finding is that, among male household heads, racial differences in home ownership and housing values have narrowed considerably - albeit, not continuously - over the twentieth century. For the most part, changes in the racial gap in ownership and in housing values over sub-periods can be attributed to changes in the racial gap in observable factors correlated with ownership and housing values, such as educational attainment (in the case of ownership) or housing characteristics (in the case of housing values). However, at certain times, changes in the racial housing gaps occurred in addition to, or in spite of, changes in observed correlates; that is, there were residual movements in the gaps. We speculate on the sources of these residual movements, particularly those that could be related to the effects of government policy via housing segregation, but we leave the task of a more complete causal analysis to future research. 


\title{
Race and Home Ownership Since 1900: Overview from the Census Data
}

\author{
Ownership
}

Information about home ownership is available in every microdata sample of the census since 1900, with the exception of $1950 .^{6}$ Dwellings were classified as owner-occupied if the owner happened to live there, though the census did not identify who within the household was the owner. We assume that the household head owned the house if the house was owner-occupied. ${ }^{7}$ In keeping with the bulk of the previous literature on racial differences in incomes, we focus on adult males. Specifically, we extracted observations of all black and white male household heads between 20 and 64 years of age who were not in school from the IPUMS samples.

Figure 1 graphs male home ownership rates by race from 1900 to 1990 . The white rate was at all times considerably higher than the black rate, and for the most part, the black and white rates moved in the same direction from decade to decade. Remarkably, not until 1970 did the black home ownership rate reach the level of the white rate at the turn of the century (46 percent). The slight declines in both the black and white rates between 1920 and 1940 were followed by sharp rises from 1940 to 1960 (24.2 points for whites and 18.6 for blacks) and continuing increases until 1980 when the rates leveled off.

Although the white level of ownership was always higher than the black level, the size of the gap varied over time, as shown in Figure 2. In numerical terms, the most significant changes occurred between 1940 and 1980; in particular, the racial ownership gap jumped by 5.5 points between 1940 and 1960 and then collapsed from 1960 to 1980, falling 7.8 points. Below, we will use a decomposition analysis of the census data to account for the factors contributing to these changes in the racial ownership gap.

Table 1 reports the size of the racial ownership gap by age group. Two interesting trend reversals are evident. First, early in the century, the ownership gap widened with age within a given census year, but 
by 1960, the gap was wider for young cohorts than old ones. In fact, aside from the oldest cohorts in 1900, the largest recorded racial gaps in home ownership rates occurred in 1960, at the tail end of the Great Migration, among 30 to 45 year olds. Second, up to 1960, as cohorts aged, the racial ownership gap almost always widened. After 1960, however, blacks began to achieve home owner status faster than whites as they aged (except for the youngest cohort). Thus, the downward swing in the ownership gap for men was not merely a function of younger, better-educated black men taking the place of older, lesseducated blacks in that year's sample; rather, the within-cohort gaps narrowed over time after 1960.

The racial differences depicted in Figures 1 and 2 and to a lesser extent in Table 1 (because Table 1 controls for age) may be due to race per se, or they may reflect correlations between race and other variables that were themselves determinants of home ownership. ${ }^{8}$ In order to measure levels and changes in the pure effects of race, we use linear probability models to estimate the relationship between various household head characteristics and the probability of home ownership. ${ }^{9}$ The list of characteristics, which is the same for all census dates, includes race, occupational status as measured by the median income of workers in that three-digit occupation in 1950, age, literacy, farm status, metropolitan status (a dummy for central city residents and a dummy for suburban residents), marital status, family size, whether the household includes more than one family, region of residence, and migrant status (a dummy for native-born inter-regional migrants and a dummy for the foreign born). ${ }^{10}$ Table 2 reports the regression results.

Consistent with the findings of Figure 1 and Table 1, race was negatively correlated with home ownership. However, the race coefficients are uniformly smaller than the racial gaps shown in Figure 1, indicating that racial differences in the variables included in the regression were responsible for some of the racial gap in home ownership. The pure effect of race (the coefficient of the race dummy) changed little between 1900 and 1940, and, unlike the raw gaps shown in Figure 2, the effect did not rise between 1940 and 1960. The coefficient declined in magnitude by 5.8 percentage points (from -0.1492 to -0.0912 ) between 1960 and 1980.

Although not the subject of this paper, the regressions reveal other aspects of change and 
continuity in the correlates of home ownership over the course of the century which are worthy of note. The age profile steepened sharply between 1940 and 1960, and the marriage indicator became strongly positive and significant as young married couples found home ownership increasingly affordable. The coefficient for the farm status variable went from strongly positive at the turn of the century to essentially zero by 1960, including a big drop between 1920 and 1940, presumably as small, family-owned farms became increasingly rare. Beginning in 1960 the foreign born became increasing less likely than natives to own a home. Finally, the substantial inter-regional differences which were apparent in 1910 had dissipated by 1990 as the high propensity for home ownership in the West and Midwest converged on that of the Northeast (omitted category). Other coefficients, however, were more stable over time. Inter-regional migrants (natives residing in a region different from their region of birth) were always less likely to own than non-migrants, as were central city residents, whereas literate men and those in relatively higher paying occupations were always more likely to own their homes.

\section{Property Values}

Since 1940 the census has reported a measure of house and property value of owner-occupied units, but inter-census comparisons must be qualified because of changes in the method of estimating value, the treatment of farm property, the intervals and top codes of the data, and the universe of homes included in the question's coverage. The most important change over time, for our purposes, is that in 1940 farms were included (though only the value of the farm house), but in 1960 rural farms were excluded and in 1980 all homes on more than ten acres were excluded. The figures in Table 3 take the census estimates at face value and make no effort to standardize the treatment of farms, but in the subsequent regression analysis (see below) all farms are excluded. ${ }^{11}$

Table 3 reports the average value of black-owned homes relative to white-owned homes for each region (first three columns) as well as the implied black-to-white ratio of housing owned per household (by 
assigning renters a value of zero) in 1940, 1960, and 1980. Among home owners, the West consistently had a high ratio of black-to-white home values relative to the rest of the country. The South, on the other hand, had by far the lowest value in 1940, but it caught up to the Midwest and Northeast by 1980 . The nationwide ratio was very low in 1940 because blacks were relatively concentrated in the South where home values were quite low compared to the rest of the country and where black home values were low relative to whites within the region. In the years between 1940 and 1980, however, the ratio of blackowned to white-owned home values increased substantially, from about 35 percent to 62 percent. The bulk of this increase occurred between 1940 and 1960.

Assigning renters a value of zero provides a measure of housing owned per household which is reported in the last three columns of Table 3. Unlike the "home owner only" ratio, this measure is sensitive to racial differences in the proportion of renters, and because a higher proportion of blacks are renters, these ratios are always lower than in the "home owner only" columns. Nevertheless, despite the rapid urbanization of blacks after 1940 (which tended to lower home ownership rates), there was a sizable increase in the black/white value ratio over time both nationally and within regions. It is worth noting that a substantial portion of the convergence of black/white housing values since 1940 appears to have been driven by changes in the South (that is, both increases in southern property values relative to the rest of the US and increases in relative black property values within the region). Because the South is now much more similar to the rest of the US than it was in 1940, it is unlikely that regional convergence will continue to propel increases in the ratio of black/white housing values. In contrast to the "home owner only" ratios of value, the ratios which include renters show a sizable increase between 1960 and 1980 as proportionately more blacks moved into the home owner category than whites.

\section{Mortgages}

The 1900, 1910, 1920, 1980, and 1990 IPUMS samples report the mortgage status of owner- 
occupied homes; that is, given that a home is owned, we know whether it is owned "free and clear" or is mortgaged. The universe of homes covered by this variable changed substantially between 1920 and 1980 . From 1900 to 1920, all owner-occupied "housing units" are included, but in 1980 only "single-unit houses" (not condominiums and not mobile homes) on less than ten acres with no business on the property are covered, whereas the 1990 sample universe includes condominiums and mobile homes. Thus, some care must be taken when making comparisons over time, but the changes in coverage are unlikely to affect the broad trends we point out here.

Table 4 reports the proportion of male-headed households with a mortgage, conditional on ownership, by race, region, and year. At the turn of the century black homeowners were less likely to hold a mortgage than white home owners, by approximately 7 percentage points. Largely, this gap was due to the black population's overwhelming concentration in the South where relatively few home owners of either race held mortgages; in fact, within three of the four regions, blacks were more likely than whites to hold a mortgage in 1900. After 1920, the national gap declined as blacks left the South and as southern financial institutions developed. By 1980, the holding of a mortgage had become virtually synonymous with home ownership for both races, and essentially identical proportions of black and white home owners held mortgages (nearly 80 percent).

\section{Understanding the Home Ownership and Value Gap: Decomposition Analysis}

The IPUMS data indicate that substantial changes in the racial gaps in home ownership and housing values occurred over the course of the century; and, in particular, substantial changes took place over the 1940 to 1980 period. In this section we use a decomposition analysis in an attempt to explain the timing of the changes in the racial gaps.

Ownership Decompositions 
In this section we use coefficients from regressions similar in character to those reported in Table 2 along with sample means of the independent variables to compute decompositions of changes over time in the racial gap in home ownership. ${ }^{12}$ The basic idea is to decompose the overall change in the ownership gap into three components: one associated with changes in the characteristics of blacks and whites; one associated with changes in how characteristics are correlated with home ownership; and another associated with changes in the distribution of residuals.

More precisely, the gap $(\mathrm{G})$ in home ownership rates $(\mathrm{H})$ at time $\mathrm{t}$ can be written as

$$
\mathrm{G}_{\mathrm{t}}=\mathrm{H}_{\mathrm{wt}}-\mathrm{H}_{\mathrm{bt}}=\left(\mathrm{X}_{\mathrm{wt}}-\mathrm{X}_{\mathrm{bt}}\right) \beta_{\mathrm{t}}+\mathrm{e}_{\mathrm{wt}}-\mathrm{e}_{\mathrm{bt}}
$$

The $\mathrm{X}$ represents the characteristics of the men in the sample (age, age squared, education, education squared, occupational status as measured by median income of workers with that three-digit occupation in 1950, region of residence, metropolitan status, migrant status, farm status, marital status, family size, and whether more than one family lives in the residence). The $\beta$ represents a vector of regression coefficients relating the various characteristics to the likelihood of home ownership, and e represents the residual term from such a regression. After adding and subtracting $\left(\mathrm{X}_{\mathrm{wt}+1}-\mathrm{X}_{\mathrm{bt}+1}\right) \beta_{\mathrm{t}}$ and rearranging terms, the change in the gap from one census $(\mathrm{t})$ to another $(\mathrm{t}+1)$ can be expressed as

$$
\begin{gathered}
G_{t+1}-G_{t}=\left[\left(X_{w t+1}-X_{b t+1}\right)-\left(X_{w t}-X_{b t}\right)\right] \beta_{t}+ \\
\left(X_{w t+1}-X_{b t+1}\right)\left(\beta_{t+1}-\beta_{t}\right)+ \\
{\left[\left(e_{w t+1}-e_{b t+1}\right)-\left(e_{w t}-e_{b t}\right)\right] .}
\end{gathered}
$$

Finally, the change in the gap can be rewritten as

$$
G_{t+1}-G_{t}=\left[\left(X_{w t+1}-X_{b t+1}\right)-\left(X_{w t}-X_{b t}\right)\right] \beta_{t}+
$$




$$
\begin{aligned}
& \left(X_{w t+1}-X_{b t+1}\right)\left(\beta_{t+1}-\beta_{t}\right)+ \\
& {\left[\left(\delta_{w t+1}-\delta_{b t+1}\right)-\left(\delta_{w t}-\delta_{b t}\right)\right] \sigma_{w t}+\left(\delta_{w t+1}-\delta_{b t+1}\right)\left(\sigma_{w t+1}-\sigma_{w t}\right)}
\end{aligned}
$$

where $\sigma_{\mathrm{wt}}$ is the standard deviation of the white residuals in year $\mathrm{t}$ and $\delta_{\mathrm{it}}$ is the "standardized residual" $\left(\mathrm{e}_{\mathrm{it}} / \sigma_{\mathrm{wt}}\right)$ with mean zero and variance one for whites. If there had been no change in the standard deviation of the white residuals between the censuses, then the fourth term would be zero and the third term would be identical to the last term of equation 2. This last step in the decomposition allows us to distinguish between changes in the residual gap driven by changes in the residuals' variance (fourth term) and those driven by changes in the relative position of blacks within the residual distribution (third term).

Table 5 describes the decomposition at the sample means for the 1940 to 1960 period using the linear probability estimates of the $\beta$ coefficients for the white population. ${ }^{13}$ Changes in the first two terms of equation 3 account for nearly all of the increase in the racial home ownership gap. ${ }^{14}$ The change in relative characteristics accounts for roughly 63 percent $(0.032 / 0.050)$ of the overall change in the racial home ownership gap, and the movements of blacks out of the South and into the central cities were the largest contributors. According to the decomposition, had it not been for the relatively large increase in black education levels between 1940 and 1960, the ownership gap would have increased by substantially more than it did. Approximately 31 percent $(0.016 / 0.050)$ of the change in the gap can be accounted for by changes in the coefficients relating the various characteristics to the propensity for home ownership. Most importantly, the sizable increase in the coefficient on education tended to increase the size of the racial ownership gap because whites had significantly higher levels of education than blacks.

Table 6 reports the decomposition for the 1960 to 1980 period, and the results differ substantially from those for the previous twenty years. From 1960 to1980, changes in characteristics and changes in coefficients account for only 39 percent of the overall decline in the home ownership gap. The relative increases in black educational attainment and occupational status are the most important changes in characteristics contributing to the gap's decline. The fall in the suburban residence coefficient also 
contributed substantially to the decline in the home ownership gap since whites were considerably more likely than blacks to reside in suburban areas. Most of the gap's decline, however, is accounted for by changes in the residuals, and in particular, by the improvement of the average black man's position within the residual distribution (as reflected in the third term of equation 3). ${ }^{15}$

\section{Value Decomposition}

Although information on the characteristics of owner-occupied housing was collected in 1940, this information was not retained at the microeconomic level, and therefore it is not included in the 1940 IPUMS sample. For 1960 and 1980, however, we can observe several dimensions of housing quality in the IPUMS: for example, the number of rooms, the number of bathrooms, the type of heating system, and the age of the building. Following the conventional "hedonic" approach taken in the urban economics literature, we assume that the logarithm of housing value is a linear function of housing characteristics:

$$
\ln \mathrm{V}=\mathrm{X} \beta+\epsilon
$$

where the X's are housing characteristics, and $\beta$ is a vector of regression coefficients. ${ }^{16}$ Changes in the racial gap in housing values are decomposed in the same manner as described in equations 1 to 3 . The regressions' explanatory variables include the house quality variables already mentioned, regional indicators, and center city and suburban indicators. The coefficients are estimated by OLS on the 1960 and 1980 samples of home owners. ${ }^{17}$

Table 7 reports decompositions of the change in the racial gap in housing values between 1960 and 1980. Regardless of whether the white or black coefficients are used, the decomposition reveals that convergence in housing characteristics was the proximate force behind the increase of black-owned house values relative to white values. Indeed, the changes in the characteristics substantially over-predict the 
magnitude of the change in relative values, implying that either changes in the hedonic prices or changes in the residual distribution offset the convergence in housing characteristics. The decomposition based on the white coefficients suggest that a widening of the residual distribution (the fourth term of equation 3 ) and a decline in blacks' average position in the standardized residual distribution (the third term) tended to offset the convergence of housing characteristics. The decomposition based on the black coefficients also reveals a decline (albeit smaller) in blacks' position in the residual distribution but, in addition, suggests that changes in the coefficients mattered. In particular, an increase in the coefficient associated with suburban residence, a decline in the coefficient associated with central city residence, and an increase in the coefficient for western residence all tended to widen the racial value gap because blacks were more concentrated than whites in central cities and less concentrated in the suburbs and the West.

\section{Segregation, Home Ownership, and Housing Values}

At the turn of the twentieth century the vast majority of African-Americans were engaged in agricultural occupations in the rural South, and most were very poor, both absolutely and relative to whites. ${ }^{18}$ As the century progressed blacks moved out of the rural South into non-farm jobs located primarily in metropolitan areas - a migration that until recently was responsible for a substantial portion of the long-term decline in the racial income gap. ${ }^{19}$ But while the regional distribution of the black population became substantially more uniform as a consequence of the Great Migration, levels of residential segregation remained remarkably high within metropolitan areas. Black migrants tended to settle in established black neighborhoods in central cities while whites moved to the suburbs. In the 1970s, middleclass blacks began to suburbanize and levels of residential segregation declined, but absolute levels of residential segregation remain high to the present day. ${ }^{20}$

The increases in home ownership, home values, and mortgage incidence discussed earlier in the paper occurred against a backdrop of long-term institutional innovation in housing markets largely 
engineered by the federal government. In the early twentieth century, purchase of a home required a substantial down payment with the remainder typically financed by a "balloon" mortgage of relatively short duration. ${ }^{21}$ One consequence, as shown in Table 4, was a relatively low incidence of mortgages, particularly in the South, where capital markets in general were underdeveloped. ${ }^{22}$ Although there is evidence that the mortgage market was already moving in the direction of lower down payments and longerterm contracts (Snowden 1996), the financial collapse in the 1930s led the federal government to redesign the mortgage lending industry in a way that made home ownership substantially more attractive.

The first successful intervention was the establishment of the Home Owner's Loan Corporation (HOLC) in 1933. The chief mission of the HOLC was to reduce the rate of foreclosure which, in the early years of the Great Depression, had risen to astonishing levels (for example, to approximately 1,000 per day in early 1933). The agency did so first by refinancing existing mortgages into long-term, self-amortizing loans at lower interest rates; and, second, by granting loans so that prior owners could recover forced-sale properties lost to foreclosure. The scope of the HOLC was enormous; between July 1933 and June 1935, the agency had provided mortgage assistance encompassing fully 10 percent of all non-farm urban owneroccupied units in the U.S.

The HOLC also systematized the mortgage appraisal process, developing elaborate, uniform procedures to assess whether a particular loan should be granted. The rationalization began with the development of a series of "Residential Security Maps," by which cities were divided into neighborhoods to be rated according to their desirability. The best areas, typically occupied by high-income professional whites, were rated " $\mathrm{A}$ " and shaded green on the maps. They were followed by somewhat less desirable "B" neighborhoods (shaded blue); "C" neighborhoods, deemed to be "declining" (shaded yellow); and, finally, "D" neighborhoods, the lowest rank and shaded red. A central aspect of the rating system was that it was based not only on the quality of the housing stock but also explicitly on the socioeconomic, ethnic, and, pointedly, the racial characteristics of the neighborhood residents. ${ }^{23}$ Use of non-housing criteria in the appraisal process did not originate with the HOLC, but both in scope and in detail, the agency's revisions 
were unprecedented. ${ }^{24}$ Private financial institutions incorporated the new rating system in their own appraisals, thereby beginning the formalization of the practice known as "red-lining." 25

Also established in the 1930s was the Federal Housing Administration (FHA). The FHA, along with a very similar program run by Veteran's Administration (VA) after the passage of the GI Bill, did not issue mortgages but rather insured them. FHA insurance reduced the risk to lenders, thereby enabling much lower down-payments (as little as 3 percent in the case of the FHA, and even zero in the case of the VA), interest rates, and closing costs.

The FHA and VA explicitly included race as a criterion in their appraisal process, following HOLC guidelines, and they monitored and predicted the residential patterns of blacks using the information to refuse insurance to neighborhoods on a wholesale basis. Furthermore, the FHA's 1939 Underwriting Manual openly recommended the use of racial restrictive covenants, clauses in housing deeds which prohibited occupancy by blacks and which the Supreme Court ruled unenforceable in 1948 (Shelley v.

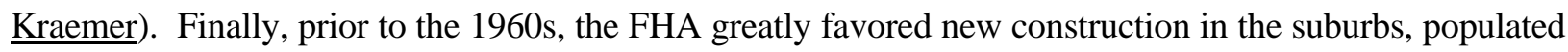
primarily by whites, while simultaneously discouraging loans for repairing and upgrading existing units in city centers. ${ }^{26}$ As with the HOLC appraisal system, FHA-VA policies of red-lining and suburban promotion were evidently adopted by banks and savings and loans.

With the advent of the Civil Rights Movement and widespread urban unrest in the 1960s, public awareness of the federal government's culpability in fostering urban decay and racial segregation in housing was heightened. One important outcome was the eventual passage of fair housing legislation in 1968 which outlawed racial discrimination in the purchase or rental of housing; several related acts were passed subsequently. ${ }^{27}$ Despite these legislative efforts, well into the 1980s and early 1990s various studies alleged that minority applicants were more likely to be denied a mortgage than otherwise identical white applicants and that prospective black home owners continued to encounter discriminatory treatment from real estate agents. ${ }^{28}$

Although racial segregation in urban life predated federal intervention in housing markets, some 
scholars have alleged that by reinforcing (and possibly enhancing) existing patterns of residential segregation, pre-1968 federal housing policy inhibited the ability of blacks to become home owners, especially in suburban areas, where housing values were rising over time relative to other areas. ${ }^{29}$ With the census information at our disposal we cannot literally identify a treatment effect of federal housing policy on racial differences in housing outcomes. However, if the net impact of red-lining-type policies on relative black home ownership had been great, we might expect to see the pure effect of race (coefficient of the race dummy in Table 2) increase substantially in magnitude between 1940 and 1960. Although the coefficient did increase in magnitude, the size of the increase $\left(0.007\right.$, or less than one percent) was very small. ${ }^{30}$

By a similar logic, if post-1960 fair housing policies improved home ownership prospects for blacks, we might expect to see the legislative imprint in the residual component of the 1960-80 decompositions in Table 6. Our finding, for example, that a substantial portion of the narrowing of the racial gap in home ownership between 1960 and 1980 was due to an improvement in the relative position of blacks in the residual distribution - in effect, an "unexplained" increase in the probability that a black male household head would become a home owner - is consistent with a positive impact of fair housing legislation. On the other hand, the decline in blacks' relative position in the residual distribution of housing values between 1960 and 1980 suggests that even if fair housing policies did enhance the ability of blacks to become home owners, they may have indirectly led to a decline in housing values (see below).

Additional insights into such policy effects can be gleaned from an exploration of the relationship between residential segregation and racial differences in housing outcomes, an exploration facilitated by the segregation indices for metropolitan areas recently calculated by Cutler, Glaeser, and Vigdor. ${ }^{31}$ If the relationship between segregation and relative black outcomes were negative, then policies that fostered segregation would clearly have been detrimental to racial convergence, as alleged by Oliver and Shapiro. Conversely, if the relationship between segregation and relative black outcomes were neutral or positive, then policies that fostered segregation would have had no effect, or else would have encouraged, racial convergence. $^{32}$ 
To this end, we estimated regressions of housing outcomes in which segregation was an additional explanatory variable. The regressions reported in Table 8 are similar in form to those in Table 2 with a few important differences. First, because the segregation measures are for cities, only those living in metropolitan areas are included in the sample. Second, because our analysis focuses on data for 1940 and 1980, we use years of education rather than literacy. Third, each regression includes city fixed effects, and so a coefficient on the level of segregation alone cannot be identified, though a coefficient on its interaction with race can be, and this coefficient measures the differential impact of segregation on blacks relative to whites. ${ }^{33}$ Thus, a positive coefficient on the interaction implies that blacks had higher ownership rates or housing values relative to whites in more segregated cities. We have chosen this fixed-effects approach to ensure that our regressions are comparable to those run by Cutler, Glaeser, and Vigdor. A key difference between our analysis and that of Cutler, Glaeser, and Vigdor is that we examine both ownership and value whereas they examine value (and rent) but not ownership.

The first key finding in Table 8 is that segregation per se was not associated with larger racial gaps in home ownership. In interpreting this result it is important to keep in mind that city-specific fixed effects are included in these regressions; that is, unobserved characteristics will bias the coefficient of interest only if those characteristics are correlated with segregation levels and have different effects on the black and white populations. In 1940, the ownership gap between blacks and whites was actually smaller in more segregated cities. This is true whether or not we control for central city residence, and whether or not we include an interaction of city size (population) and race (not reported in the table). In 1980, the ownership gap is again smaller in more segregated cities if we control for central city residence, and it is uncorrelated with segregation if we do not. ${ }^{34}$ This implies that there is a positive correlation between central city residence and the variable interacting race and segregation, and a negative correlation between central city residence and ownership. Intuitively, the implication is that blacks are more concentrated in the central city areas of more segregated cities, and because ownership is strongly negatively correlated with central city residence, the ownership gap between blacks and whites tends to widen with the concentration of blacks in 
central cities. When we do not control for central city residence, the segregation variable picks up this effect, and so the coefficient in less positive. In any case, it is difficult to argue on the basis of the 1940 or the 1980 data that residential segregation impeded black access to home ownership; at worst, it seems that segregation has had no correlation with the racial gap in home ownership rates across cities. ${ }^{35}$

Another piece of evidence along these same lines comes from the census data for mortgages in 1980. Regressions (not reported) similar in form to those for ownership in Table 8 find that blacks in metropolitan areas were indeed less likely to have a mortgage than observationally similar whites (not conditioning on home ownership), but the size of the gap between blacks and whites is uncorrelated with the degree of segregation in the city if central city status is not included as a regressor. If central city status is included, the mortgage gap is narrower in more segregated cities. These results are not surprising because, as noted earlier in the paper, home owners in 1980 were very likely to have a mortgage, and so the regression results are very similar to those run for ownership.

However, these findings do not necessarily imply that the effect of segregation on the racial gap in housing outcomes was neutral. ${ }^{36}$ In particular, segregation might have promoted black home ownership only by lowering the value of the existing stock of housing in black neighborhoods below what it would be in the absence of segregation. As noted earlier in the paper, it is impossible to control for housing characteristics in 1940, but Table 8 suggests that in the 1940 cross-section an increase in segregation was accompanied by an increase in black housing values relative to whites. ${ }^{37}$ Thus, both the home ownership gap and the home value gap were smaller in more segregated cities in 1940, implying that the smaller gap in home ownership rates was not due to relatively low prices for black-owned housing. With the data at hand it is not possible to pin down an explanation of this finding, but one possibility is that financial institutions serving black clientele were more developed in more segregated cities. ${ }^{38}$ Another potential explanation is that in 1940, blacks were sorted (more so than whites) across cities on the basis of some unobserved component which was positively correlated with both segregation and positive housing outcomes. ${ }^{39}$ 
The most important change in the nature of segregation's correlation with black housing values is the emergence of a strong negative coefficient on the race-segregation interaction sometime after $1940 .{ }^{40}$ By 1980, black housing values in more segregated cities were substantially less relative to whites than in less segregated cities. This finding holds whether or not housing characteristics are included in the regression and whether or not a race-population interaction variable is added..$^{41}$

As noted earlier, because we are unable to estimate similar regressions for the intervening census years between 1940 and 1980, we cannot date precisely when the negative association between segregation and relative black housing values first emerged. Related work by Wilson, however, suggests that the change can be dated to the 1970s, a timing that is consistent with indirect effects of fair housing legislation. ${ }^{42}$ According to Wilson the legislation enabled middle-class blacks, for the first time, to vacate the ghetto for owner-occupied homes in the suburbs. Although the exodus of middle class blacks was relatively modest, and far from the sole cause of urban decline, the end result was a substantial deterioration in the "quality" of black neighborhoods in central cities, as evidenced by increases in a variety of adverse socioeconomic outcomes, such as idleness, low wages, and the incidence of female-headed families. ${ }^{43}$ Although these changes did not lead to a sign reversal in the relationship between segregation and relative black home ownership, the results in Table 8 suggest they apparently produced a widening in the racial gap in house values in the nation's most segregated cities by 1980 .

\section{Implications and Conclusions}

Our findings bear on several important aspects of the evolution of black-white differences in economic status in the twentieth century. The proportion of black male household heads who were homeowners rose by 34.4 percentage points between 1900 and 1990. The corresponding increase among white male household heads was smaller (28.1 percentage points), and thus, the racial gap in ownership fell. The racial gap in ownership did not, however, decline consistently across census years. The gap 
widened between 1940 and 1960, when increasing numbers of blacks left the rural South in search of a better life in the urban North. Thus, a consequence of the Great Migration, one that is largely unrecognized in the literature, was a widening racial gap in home ownership rates. The gap widened because rates of ownership for both races were higher in the South than (in particular) in the Northeast and because ownership rates were far lower among residents of central cities than elsewhere. However, the value of owner-occupied housing was higher outside the South, and thus the movement of blacks into home ownership status in central cities was associated with a rise in the black/white ratio of housing values. The racial gap in housing values continued to narrow between 1960 and 1980, entirely because black homeowners acquired houses whose characteristics were increasingly similar to those owned by whites.

Although the data we have examined cannot assess directly the effects of federal housing policies, our examination of segregation levels and housing outcomes suggests that if residential segregation had a negative impact on black housing wealth accumulation, it was not through a denial of access to home ownership per se, but rather through an adverse effect on the relative value of black owned property. However, this negative correlation between property values and segregation levels was not evident in 1940, and so it seems that segregation did not cause a deterioration in the relative value of black owned property but, rather, something correlated with or working through segregation did. Moreover, whatever the adverse consequences of the policies cited by Oliver and Shapiro might have been, they were not large enough to offset the long-run convergence of black/white average property values shown in Table 3 . It bears repeating, however, that much of the post-1940 increase in the ratios reported in Table 3 was driven by the economic convergence of the South on the rest of the country, a trend which is unlikely to be a source of racial wealth convergence in the future.

The analysis in this paper could be extended in at least three directions. First, a direct assessment of the impact of federal housing policies could be undertaken by assembling city-level policy measures, though of course, the potential endogeneity of such measures would present substantial difficulties. Second, we have not attempted to estimate the net cost of segregation for blacks in terms of total housing 
value, but the results of this paper are suggestive of how different elements would enter into such a calculation. Third, other studies have noted that family structure is strongly associated with home ownership; in particular, female-headed households have much lower rates of home ownership than other types of families. ${ }^{44}$ Thus a full assessment of twentieth century trends in racial differences of housing outcomes will require taking account of changing racial differences in household structure, in particular, the relatively fast growth of female headed households among black families. ${ }^{45}$ 


\section{$\underline{\text { Footnotes }}$}

1. Smith and Welch, "Black Economic Progress"; Margo, Race and Schooling; Donohue and Heckman, "Continuous versus Episodic Change"; Collins, "African-American" and "Race, Roosevelt."

2.Contemporary racial differences in home ownership and housing wealth and their correlates have been the subject of numerous studies by economists (see, for example, Blau and Graham 1990, and Caudill and Long 1992) but, to our knowledge, there are no such studies that span the twentieth century.

3. Based on the 1988 wave of the SIPP (Survey of Income and Program Participation), home equity accounted for about 43 percent of net worth for white households but 63 percent of net worth for black households; see Oliver and Shapiro, Black Wealth/White Wealth, p. 106.

4. See Ruggles and Sobek, Integrated Public Use Microdata Series.

5. Cutler, Glaeser, and Vigdor, "Rise and Decline."

6.The published census volumes provide data on home ownership by race, albeit somewhat in somewhat different form than those studied here; in particular, the published data pertain to the ownership status of dwelling units occupied by black families. Typically, these data were cross-classified by only a few correlates (for example, region) and thus cannot be used for the type of multivariate decompositions presented in this paper (see the text).

7. Excluding households with multiple fathers or multiple mothers (signs of extended family household arrangements) appears to have little effect on our results.

8. A simple economic model of home ownership posits that household heads choose an ownership status $\mathrm{O}(\mathrm{wn})$ or $\mathrm{R}(\mathrm{ent})$ - in conjunction with a vector of housing characteristics $\mathrm{X}$, and a vector of non-housing goods $\mathrm{C}$, to maximize an inter-temporal household utility function $\mathrm{U}$, subject to a household budget constraint which is a function of current and expected future household incomes; a set of current and expected future hedonic prices of X; net current and expected future costs of home ownership (e.g., transaction costs, see below), which may be fixed or variable; and current and expected future prices of C. Let $\mathrm{V}$ be the maximized value of $\mathrm{U}$. Because housing is also a store of value, $\mathrm{V}$ reflects the value to the 
household of holding some of its wealth in the form of owner-occupied housing. In the current period, the household chooses to own if $\mathrm{V}(\mathrm{O})>\mathrm{V}(\mathrm{R})$ and chooses to rent otherwise. Essentially, choosing to be a homeowner is choosing to self-produce "housing services" from X, a decision that by its very nature is bundled with the decision to hold a portion of household wealth in the form of owner-occupied housing. Transparently, the decision to own implies that the owner-occupier can produce housing services more cheaply than renting directly from a landlord (that is, the net costs of ownership are negative). This could happen, in particular, if the household head has private information and can more effectively internalize any externalities that might arise in the course of occupying the property (for example, the threat of damaging the property through misuse by a household member). The decision to hold some wealth as owneroccupied housing may be rationalized in a similar manner. In addition, ownership may also confer political standing, or cheaper access to local public goods (for example, public schools); households that place a relatively high value on either would prefer, other things equal, to be homeowners; in terms of the model, home ownership lowers the relative price of a subset of the goods making up C. Some of the variables in the regressions can be given an interpretation in terms of such a model. For example, large families may impose greater externalities than small families, requiring a rental premium for family size that a household might prefer not to pay. Life-cycle motives for accumulating wealth in the form of owner-occupied housing would be reflected in differences in home ownership by age and possibly marital status. Because housing has always been expensive to purchase (relative to other consumer durables) variables related to income occupational status, education, age - are expected to have positive effects on home ownership, effects that may have increased at the margin after World War Two with changes in the federal tax code (for example, increases in marginal tax rates, see footnote 13) that subsidized home ownership (this hypothesis is borne out by the data; see Table 2). Finally, we expect to see residual differences in home ownership across locations, either because of differences in transaction costs, or in the nature of mortgage markets. Our goal in Table 2 is not to evaluate the model per se, but rather to determine how much of the racial gaps in home ownership remain after controlling for factors other than race. 
9.Probit models give substantively identical results.

10.Literacy was measured directly in 1900, 1910 and 1920. From 1940 to 1990 we code an individual as literate if he completed at least two years of schooling; see Margo, Race and Schooling.

11. Excluding the farms from 1940's sample has a small effect on the black/white value ratio, raising the US figure to about 0.20 for all household heads and 0.37 for home owners.

12. For the decomposition analysis, regressions are run separately by race and a measure of years of education is used rather than literacy; otherwise the regressions are similar to those in Table 2. See Juhn, Murphy, and Pierce, “Accounting"; Maloney, "Wage Compression”; or Margo, "Explaining” for earlier applications of this methodology.

13. In principle, the decomposition can be done using the coefficients from either the white or black regressions. Here we follow Juhn, Murphy, and Pierce, "Accounting” and Margo, "Explaining" by using the coefficients from the white regression. Using the black coefficients in the 1940-60 decomposition, the change in coefficients from 1940 to 1960 played a more important role in accounting for the widening ownership gap than when white coefficients were used (59 percent rather than 31 percent). In particular, a substantial increase in the occupation coefficient tends to widen the gap, but the education coefficient does not increase much for blacks and so this does not contribute much to the widening.

14. The total change (1940 to 1960) to be explained in Table 5 is only 5.01 points compared to 5.44 points from Table 1 because a number of observations are excluded from Table 5 that are included in Table 1 (in particular, those with no reported occupation are dropped from the regressions of Table 5).

15.Again, the results differ somewhat when the black coefficients are used in the decomposition. In that case, changes in the characteristics and coefficients account for 83 percent of the change in the gap.

Declines in both the occupation coefficient and the occupational gap contributed significantly to the closing of the ownership gap, as did the closing of the education gap.

16. See Rosen, "Hedonic Prices."

17.We have also estimated the value regressions using a "Heckit" selection-bias model; specifically, we 
used probit analysis to estimate the probability of home ownership, from which we construct the selection bias correction term (the inverse Mills ratio), which was then added to the value equation. The substantive findings were unaffected.

18. Ransom and Sutch, One Kind; Higgs, "Accumulation"; Margo, "Accumulation."

19. Smith and Welch, "Black Economic Progress"; Margo, Race and Schooling; Donohue and Heckman, “Continuous versus Episodic"; Collins, “African-American” and "Race, Roosevelt."

20. Wilson, Truly Disadvantaged; Cutler, Glaeser, and Vigdor, "Rise and Decline."

21.In a study of 22 cities over the period 1911-1914, the average down payment was approximately 68 percent of the purchase price (Winnick, American Housing, pp. 68-69). Though there is some evidence that down payments had fallen by the 1920s, mortgage contracts were still relatively short in duration (6-11 years).

22. Ransom and Sutch, One Kind.

23. Religion was also a criterion; Jewish neighborhoods were routinely ranked B or below, regardless of the incomes of the residents or quality of housing.

24. The HOLC's use of race in ranking neighborhoods notwithstanding, there is some evidence that the agency itself was relatively unbiased in issuing loans. For example, in Memphis, Tennessee in 1939, fully 68 percent of all HOLC loans went to households living in C and D rated neighborhoods (Jackson, Crabgrass, p. 202).

25. For additional discussion of red-lining and some empirical evidence, see Benston, Horsky, and Weingartner, Empirical Study and Benston, "Mortgage Redlining." Lang and Nakamura, "Model of Redlining" model red-lining as the response to an information externality. If the perceived risk of a loan (relative to its return) is a negative function of neighborhood "quality" and it is costly for lenders to acquire information about prospective borrowers, then it may be privately optimal for the lender to deny loans (redline). When individuals sort into neighborhoods on the basis of race or other characteristics, the red-lining policy may take into account such characteristics, similar to "statistical discrimination" models of the labor 
market (see Lundberg and Startz, "Private Discrimination." However, Lang and Nakamura point out that, while red-lining may be privately optimal, the social optimum may compel the government, or other authority, to prohibit the use of race as a signal (Lundberg and Startz make a similar argument in the case of labor market discrimination).

26. For example, between 1933 and 1960, the county of St. Louis (which includes the urban periphery) received five times as much mortgage insurance as did the City of St. Louis, far in excess of its per-capita (or any other reasonable) share (Jackson, Crabgrass, p. 210).

27. For example, the Home Mortgage Disclosure Act (1975) required lenders to disclose information on recipients of loans; the 1989 amendment added application and rejection rates by race, gender and income to the disclosure requirements. The Community Reinvestment Act (1977) obligated lenders to be sensitive to local credit demands, and provides regulators with the ability to treat performance under the act as a factor in considering bank mergers.

28. Yinger, "Measuring" and Closed Doors; Canner and Passmore, "Home Purchase"; Munnell et al. "Mortgage Lending."

29. Oliver and Shapiro, Black Wealth/White Wealth, p. 16. Oliver and Shapiro also point out indirect racial effects via the tax code. Low down payments allowed prospective home buyers to leverage to a far greater extent; by making it easier to assume risk, the FHA made it possible for home owners to experience (ex post) higher capital gains, which were generally taxed at a lower rate than other forms of income.

Second, mortgage interest payments could be deducted from taxable income if taxpayers itemized. Because blacks had lower taxable incomes than whites, were less likely to be home owners than whites, and owned less valuable housing than whites, whites benefitted disproportionately. The alternative to Oliver and Shapiro is that federal policy merely codified long-standing private incentives for households to sort themselves into groups; on such incentives, see Schelling, Micromotives.

30. The decompositions in Table 5 show that the racial gap in home ownership widened by about 1.1 percentage points between 1940 and 1960 due to a deterioration in blacks' position in the residual home 
ownership distribution. Such a deterioration is consistent with the hypothesis that redlining made it more difficult for blacks to become home owners, relative to whites, all factors other than race held constant. However, the impact appears to have been modest quantitatively. Yet another way to make the same point is to observe that, while blacks locating in central cities after 1940 had low rates of home ownership relative to suburban whites, central city residents, regardless of race, had low rates of home ownership long before 1940; that is, long before the "rationalization" of redlining.

31. Cutler, Glaeser, and Vigdor, "Rise and Decline."

32. We use the dissimilarity indices based on census tract level data from Cutler, Glaeser and Vigdor, "Rise and Decline." The 1940 index is computed at using the central city only, whereas the 1980 index is computed using the entire Statistical Metropolitan Area. In 1960 the correlation between city-based and SMA-based dissimilarity indices is 0.82 (p. 500). Segregation measures are available for a much larger number of urban areas in 1980 than 1940, so we run the 1980 regressions both with and without the "new" cities.

33. Unfortunately, the 1960 IPUMS does not report metropolitan area data, and so we cannot evaluate the connection between segregation and housing outcomes in that year. The 1970 IPUMS does not identify metropolitan area and center city status within the same sample, and so investigations of that year are also compromised.

34.Limiting the sample to include only those living in cities which are also included in the 1940 sample, we find a similar pattern.

35.Of course, it is still possible that government policies affected black home ownership rates through channels other than segregation.

36.Cutler and Glaeser, "Are Ghettos Good" show a negative relation between segregation and a number of non-housing outcomes, and the literature on "spatial mismatch" argues that central city residence may have a negative impact on black employment and earnings. Collins and Margo, "Residential Segregation" and Vigdor, "Locations" show that this connection is a relatively recent historical phenomenon: up to 1970 such 
adverse effects are weaker or non-existent.

37.We have also estimated this value equation using the Heckit procedure; the substantive findings with respect to the race-segregation interaction effect were unaffected.

38.As Wilson, Truly Disadvantaged, points out, middle (and upper) class blacks were largely excluded from the suburbs prior to fair housing legislation. In a highly segregated city, therefore, black neighborhoods probably contained relatively more middle-class black households, creating a bigger potential market for financial services, including mortgages; any such tendency may have been reinforced by the fact that larger cities (in terms of population) tended to be more segregated.

39. See Vigdor, "Pursuit" for an analysis of the geographic sorting of black migrants.

40. The positive coefficient on the black indicator variable is unusual. At average levels of segregation, the overall effect of being black, a combination of the indicator and interaction terms, is still strongly negative. 41.Again, a Heckit selection approach yields similar results.

42. Wilson, Truly Disadvantaged.

43. See Cutler and Glaeser, "Are Ghettos Good”; Collins and Margo, "Residential Segregation”; and Vigdor, "Locations."

44. For example, see Blau and Graham, "Black-White Differences." We have made some preliminary estimates that indicate that the post-1960 downswing in the racial gap in home ownership (shown in Figure 1) is substantially dampened when female-headed households are added to the sample.

45. Wilson, Truly Disadvantaged. 


\section{$\underline{\text { References }}$}

Blau, F. D. and Graham, J.W. (1990), "Black-White Differences in Wealth and Asset Composition," Quarterly Journal of Economics, 105, 321-339.

Benston, G. J. (1979), “Mortgage Redlining Research: A Review and Critical Analysis,” In Conference Series 21, The Regulation of Financing Institutions. Boston: Federal Reserve Bank of Boston. Pp. 144-195.

Benston, G. J., Horsky, D. and Weingartner, H.M. (1978), An Empirical Study of Mortgage Redlining. New York: Salomon Brothers Center for the Study of Financial Institutions, New York University Graduate School of Business.

Canner, G. B. and Passmore, W. (1995), "Home Purchase Lending in Low-Income Neighborhoods and to Low-Income Borrowers," Federal Reserve Bulletin, 81, 71-103.

Collins, W. J. (1999), “African-American Economic Mobility in the 1940s: A Portrait from the Palmer Surveys," Journal of Economic History, forthcoming.

Collins, W. J. (1999), "Race, Roosevelt, and Wartime Production: Fair Employment in World War II Labor Markets," American Economic Review, forthcoming.

Collins, W. J. and Margo, R. A. (1999), "Residential Segregation and Socioeconomic Outcomes: When Did Ghettos Go Bad?" Economics Letters, forthcoming.

Cutler, D. M. and Glaeser, E.L. (1997), “Are Ghettos Good or Bad?” Quarterly Journal of Economics, $112,827-72$.

Cutler, D. M., Glaeser, E. L., and Vigdor, J. L. (1999), “The Rise and Decline of the American Ghetto,” Journal of Political Economy, 107, 455-506.

Donohue, J. and Heckman, J. (1991), “Continuous Versus Episodic Change: The Impact of Civil Rights Policy on the Economic Status of Blacks," Journal of Economic Literature, 29, 1604-1643.

Higgs, R.. (1982), “Accumulation of Property by Southern Blacks Before World War One,” American Economic Review, 72, 725-737. 
Jackson, K. T. (1985), Crabgrass Frontier: The Suburbanization of the United States. New York: Oxford University Press.

Juhn, C., Murphy, K. and Pierce, B. (1991), “Accounting for the Slowdown in Black-White Wage Convergence.” In M. Kosters (Ed.) Workers and Their Wages: Changing Patterns in the United States. Washington: AEI Press. Pp. 107-143.

Lang, W. W. and L.I. Nakamura (1993), “A Model of Redlining,” Journal of Urban Economics, 33, 223234.

Long, J.E. and S. B. Caudill (1992), "Racial Differences in Home Ownership and Housing Wealth, 19701986,” Economic Inquiry, 30, 83-100.

Lundberg, S. J. and R. Startz (1983), "Private Discrimination and Social Intervention in Competitive Labor Markets," American Economic Review, 73, 340-347.

Maloney, T. N. (1994), "Wage Compression and Wage Inequality Between Black and White Males in the United States, 1940-1960," Journal of Economic History, 54, 358-396.

Margo, R. A. (1984), “Accumulation of Property by Southern Blacks Before World War One: Comment and Further Evidence,” American Economic Review, 74, 768-776.

Margo, R. A. (1990), Race and Schooling in the South, 1880-1950: An Economic History. Chicago: University of Chicago Press.

Margo, R. (1995), “Explaining Black-White Wage Convergence, 1940-1950,” Industrial and Labor Relations Review, 48, 470-481.

Munnell, A., Tootell, G.M.B., Browne, L. E., McEneaney, J. (1996), "Mortgage Lending in Boston: Interpreting HMDA Data," American Economic Review, 86, 25-53.

Oliver, M. L. and Shapiro, T.M. (1995), Black Wealth/White Wealth: A New Perspective on Racial Inequality. New York: Routledge.

Ransom, R. and Sutch, R. (1977), One Kind of Freedom: The Economic Consequences of Emancipation. New York: Cambridge University Press. 
Rosen, S. (1974), "Hedonic Prices and Implicit Markets: Product Differentiation in Pure Competition," Journal of Political Economy, 82, 34-55.

Ruggles, S. and Sobek, M. (1997), Integrated Public Use Microdata Series. Minneapolis: Historical Census Projects, University of Minnesota.

Schelling, T. (1978), Micromotives and Macrobehavior. New York: W.W. Norton.

Smith, J. and Welch, F. (1989), "Black Economic Progress after Myrdal,” Journal of Economic Literature, 27, 519-564.

Snowden, K. A. (1996), "Building and Loan Associations, 1880-93: Information Boundaries and the Origins of Localization in the Residential Mortgage Market," unpublished paper, Department of Economics, University of North Carolina at Greensboro..

Vigdor, J. L. (1999), “Locations, Outcomes, and Selective Migration.” Unpublished paper, Terry Sanford Institute of Public Policy, Duke University.

Vigdor, J. L. (1999), “The Pursuit of Opportunity: The Extent and Impact of Selective Black Migration.” Unpublished paper, Terry Sanford Institute of Public Policy, Duke University.

Wilson, W. J. (1987), The Truly Disadvantaged: The Inner City, the Underclass, and Public Policy. Chicago: University of Chicago Press.

Winnick, L. (1957), American Housing and its Use: The Demand for Shelter Space. New York: John Wiley and Sons.

Yinger, J. (1986), "Measuring Racial Discrimination with Fair Housing Audits: Caught in the Act," American Economic Review, 76, 881-893.

Yinger, J. (1995), Closed Doors, Opportunities Lost: The Continuing Costs of Housing Discrimination. New York: Russell Sage Foundation. 
Table 1: White - Black Gap in Male Home Ownership Rates 1900-90

\begin{tabular}{|c|c|c|c|c|c|c|c|c|c|c|}
\hline Birth Cohort & 1900 & 1910 & 1920 & 1930 & 1940 & 1950 & 1960 & 1970 & 1980 & 1990 \\
\hline $1836-40$ & 37.25 & & & & & & & & & \\
\hline $1841-45$ & 29.85 & & & & & & & & & \\
\hline $1846-50$ & 29.78 & 26.40 & & & & & & & & \\
\hline $1851-55$ & 26.42 & 24.19 & & & & & & & & \\
\hline $1856-60$ & 23.30 & 28.31 & 27.65 & & & & & & & \\
\hline $1861-65$ & 20.04 & 25.97 & 26.99 & & & & & & & \\
\hline $1866-70$ & 20.75 & 23.24 & 29.58 & ----- & & & & & & \\
\hline $1871-75$ & 11.82 & 18.02 & 27.05 & ----- & & & & & & \\
\hline $1876-80$ & 7.89 & 15.70 & 22.99 & ----- & 23.63 & & & & & \\
\hline $1881-85$ & & 9.29 & 19.92 & ----- & 25.41 & & & & & \\
\hline $1886-90$ & & 6.39 & 17.40 & ----- & 24.47 & ----- & & & & \\
\hline $1891-95$ & & & 11.46 & ----- & 22.27 & ----- & & & & \\
\hline $1896-1900$ & & & 7.80 & ----- & 23.08 & ----- & 18.13 & & & \\
\hline 1901-05 & & & & ----- & 20.11 & ----- & 22.48 & & & \\
\hline $1906-10$ & & & & ----- & 17.14 & ----- & 24.50 & 19.68 & & \\
\hline $1911-15$ & & & & & 11.12 & ----- & 28.36 & 20.33 & & \\
\hline $1916-20$ & & & & & 7.63 & ----- & 30.71 & 23.90 & 18.16 & \\
\hline $1921-25$ & & & & & & ----- & 32.26 & 24.19 & 17.81 & \\
\hline $1926-30$ & & & & & & ----- & 31.84 & 26.11 & 17.87 & 17.09 \\
\hline $1931-35$ & & & & & & & 26.09 & 25.99 & 17.17 & 15.70 \\
\hline $1936-40$ & & & & & & & 15.54 & 27.53 & 19.91 & 18.84 \\
\hline $1941-45$ & & & & & & & & 21.18 & 22.64 & 18.57 \\
\hline $1946-50$ & & & & & & & & 10.42 & 21.12 & 18.68 \\
\hline $1951-55$ & & & & & & & & & 20.86 & 21.95 \\
\hline $1956-60$ & & & & & & & & & 15.51 & 24.39 \\
\hline $1961-65$ & & & & & & & & & & 21.36 \\
\hline $1966-70$ & & & & & & & & & & 13.03 \\
\hline Average Gap & 24.33 & 21.41 & 22.86 & $-\overline{----}$ & 21.90 & $-\overline{----}$ & 27.34 & 23.44 & $\overline{19.56}$ & 19.51 \\
\hline White Average & 46.16 & 47.11 & 47.50 & ----- & 42.19 & ----- & 66.39 & 69.66 & 73.44 & 71.52 \\
\hline Black Average & 21.84 & 25.70 & 24.64 & ---- & 20.29 & ---- & 39.05 & 46.22 & 53.88 & 52.01 \\
\hline
\end{tabular}

Notes: Samples include men aged 20-64 who were household heads and were not in school. The individual is counted as an "owner" if he lives in owner-occupied housing.

Source: IPUMS (Ruggles and Sobek 1997). For 1990, the 1\% unweighted sample is used. 
Table 2: Correlates of Home Ownership

\begin{tabular}{|c|c|c|c|c|c|c|c|c|}
\hline & 1900 & 1910 & 1920 & 1940 & 1960 & 1970 & 1980 & 1990 \\
\hline \multirow[t]{2}{*}{ Black } & -0.1551 & -0.1505 & -0.1711 & -0.1418 & -0.1492 & -0.1270 & -0.0912 & -0.0973 \\
\hline & $(0.0135)$ & $(0.0069)$ & $(0.0057)$ & $(0.0037)$ & $(0.0032)$ & $(0.0028)$ & $(0.0024)$ & $(0.0027)$ \\
\hline \multirow[t]{2}{*}{ Age } & 0.0255 & 0.0264 & 0.0238 & 0.0249 & 0.0479 & 0.0500 & 0.0432 & 0.0437 \\
\hline & $(0.0024)$ & $(0.0013)$ & $(0.0011)$ & $(0.0007)$ & $(0.0006)$ & $(0.0005)$ & $(0.0004)$ & $(0.0005)$ \\
\hline \multirow[t]{2}{*}{$\mathrm{Age}^{2}$} & -0.0002 & -0.0002 & -0.0001 & -0.0001 & -0.0004 & -0.0005 & -0.0004 & -0.0004 \\
\hline & $(0.0000)$ & $(0.0000)$ & $(0.0000)$ & $(0.0000)$ & $(0.0000)$ & $(0.0000)$ & $(0.0000)$ & $(0.0000)$ \\
\hline \multirow[t]{2}{*}{ Literacy } & 0.1258 & 0.1150 & 0.1282 & 0.0969 & 0.1150 & 0.1313 & 0.1470 & 0.1201 \\
\hline & $(0.0123)$ & $(0.0069)$ & $(0.0062)$ & $(0.0044)$ & $(0.0058)$ & $(0.0064)$ & $(0.0074)$ & $(0.0060)$ \\
\hline \multirow[t]{2}{*}{ Occupation } & 0.0037 & 0.0035 & 0.0044 & 0.0051 & 0.0062 & 0.0054 & 0.0050 & 0.0050 \\
\hline & $(0.0004)$ & $(0.0002)$ & $(0.0002)$ & $(0.0001)$ & $(0.0001)$ & $(0.0001)$ & $(0.0001)$ & $(0.0001)$ \\
\hline \multirow[t]{2}{*}{ Farm } & 0.2567 & 0.1979 & 0.1806 & 0.0831 & -0.0028 & 0.0416 & -0.0074 & 0.0192 \\
\hline & $(0.0092)$ & $(0.0050)$ & $(0.0044)$ & $(0.0028)$ & $(0.0036)$ & $(0.0043)$ & $(0.0039)$ & $(0.0049)$ \\
\hline \multirow[t]{2}{*}{ Family Size } & 0.0067 & 0.0018 & 0.0076 & 0.0044 & 0.0177 & 0.0222 & 0.0197 & 0.0145 \\
\hline & $(0.0017)$ & $(0.0009)$ & $(0.0008)$ & $(0.0005)$ & $(0.0005)$ & $(0.0005)$ & $(0.0005)$ & $(0.0006)$ \\
\hline \multirow{2}{*}{ Multifamily } & 0.0762 & -0.0151 & 0.0046 & 0.0284 & 0.0289 & 0.0204 & -0.0149 & -0.0068 \\
\hline & $(0.0131)$ & $(0.0051)$ & $(0.0049)$ & $(0.0035)$ & $(0.0053)$ & $(0.0049)$ & $(0.0032)$ & $(0.0029)$ \\
\hline \multirow[t]{2}{*}{ Married } & 0.0006 & -0.0206 & -0.0094 & 0.0267 & 0.2251 & 0.2524 & 0.2657 & 0.2296 \\
\hline & $(0.0128)$ & $(0.0070)$ & $(0.0061)$ & $(0.0040)$ & $(0.0036)$ & $(0.0029)$ & $(0.0022)$ & $(0.0023)$ \\
\hline \multirow[t]{2}{*}{ Central City } & -0.2072 & -0.1646 & -0.1076 & -0.1366 & -0.1321 & -0.1156 & -0.1243 & -0.1455 \\
\hline & $(0.0101)$ & $(0.0050)$ & $(0.0039)$ & $(0.0025)$ & $(0.0022)$ & $(0.0020)$ & (0.0019) & $(0.0021)$ \\
\hline \multirow[t]{2}{*}{ Suburban } & -0.0852 & -0.0199 & 0.0096 & 0.0394 & 0.0783 & 0.0276 & -0.0052 & -0.0056 \\
\hline & $(0.0137)$ & $(0.0066)$ & $(0.0062)$ & $(0.0028)$ & $(0.0021)$ & $(0.0019)$ & $(0.0016)$ & $(0.0017)$ \\
\hline \multirow[t]{2}{*}{ Midwest } & 0.0697 & 0.1021 & 0.1027 & 0.0925 & 0.1050 & 0.0833 & 0.0754 & 0.0380 \\
\hline & $(0.0094)$ & $(0.0050)$ & $(0.0041)$ & $(0.0026)$ & $(0.0022)$ & $(0.0020)$ & $(0.0019)$ & $(0.0022)$ \\
\hline \multirow[t]{2}{*}{ South } & -0.0097 & 0.0277 & 0.0343 & 0.0663 & 0.0711 & 0.0591 & 0.0515 & 0.0188 \\
\hline & $(0.0110)$ & $(0.0058)$ & $(0.0048)$ & $(0.0029)$ & $(0.0023)$ & $(0.0020)$ & $(0.0018)$ & $(0.0020)$ \\
\hline \multirow[t]{2}{*}{ West } & 0.1012 & 0.1906 & 0.1334 & 0.1505 & 0.0876 & 0.0366 & 0.0348 & -0.0292 \\
\hline & $(0.0171)$ & $(0.0081)$ & $(0.0064)$ & $(0.0036)$ & $(0.0028)$ & $(0.0024)$ & $(0.0021)$ & $(0.0022)$ \\
\hline \multirow[t]{2}{*}{ Inter-Reg. Mig. } & -0.0391 & -0.0487 & -0.0554 & -0.0607 & -0.0631 & -0.0552 & -0.0498 & -0.0566 \\
\hline & $(0.0124)$ & $(0.0065)$ & $(0.0053)$ & $(0.0031)$ & $(0.0023)$ & $(0.0020)$ & $(0.0017)$ & $(0.0027)$ \\
\hline \multirow[t]{2}{*}{ Foreign Born } & 0.0258 & -0.0115 & -0.0109 & -0.0009 & -0.0876 & -0.1357 & -0.1579 & -0.1646 \\
\hline & $(0.0091)$ & $(0.0049)$ & $(0.0041)$ & $(0.0030)$ & $(0.0032)$ & $(0.0030)$ & $(0.0026)$ & $(0.0027)$ \\
\hline \multirow[t]{2}{*}{ Constant } & -0.5781 & -0.5327 & -0.5670 & -0.6721 & -1.1146 & -1.1425 & -0.8870 & -0.8486 \\
\hline & $(0.0507)$ & $(0.0266)$ & $(0.0227)$ & $(0.0145)$ & $(0.0130)$ & $(0.0116)$ & $(0.0113)$ & $(0.0118)$ \\
\hline $\mathrm{N}$ & 16569 & 62800 & 93281 & 233439 & 285725 & 326740 & 375684 & 318799 \\
\hline $\mathrm{R}^{2}$ & 0.22 & 0.18 & 0.15 & 0.15 & 0.18 & 0.22 & 0.25 & 0.25 \\
\hline
\end{tabular}

Notes: The dependent variable is home ownership (equals 1 if residing in owner occupied dwelling).

Estimates are of a linear probability model. Standard errors are in parentheses.

Source: IPUMS (Ruggles and Sobek 1997). For 1990, the $1 \%$ metro sample is used with household 
weights. The unweighted $1 \%$ sample does not report values for the metro variable. 
Table 3: Black/White Average Property Values, Male Household Heads

\begin{tabular}{lcccccc}
\hline & \multicolumn{3}{c}{ Home Owners } & \multicolumn{3}{c}{ Home Owners and Renters } \\
\hline \multirow{2}{*}{ Northeast } & 0.6678 & 0.6465 & 0.6461 & 0.1965 & 0.2940 & 0.3359 \\
Midwest & 0.6183 & 0.7119 & 0.6255 & 0.2853 & 0.3709 & 0.4325 \\
South & 0.3693 & 0.5196 & 0.6320 & 0.1855 & 0.3126 & 0.4726 \\
West & 0.6397 & 0.7446 & 0.7766 & 0.4195 & 0.5023 & 0.5477 \\
US & 0.3546 & 0.5589 & 0.6172 & 0.1705 & 0.3168 & 0.4305 \\
\hline
\end{tabular}

Notes: Renters are assigned a property value of zero. Property values in the census are top-coded (that is, properties valued at greater than a maximal value are set equal to the maximal value). The top three percent of households in 1960 and top one percent in 1980 are top-coded, but 1940 is not top-coded. The average value of the top coded category in 1960 is estimated by multiplying the top-code by the ratio of the average value of homes in the top three percent in 1940 to the value of homes at the $97^{\text {th }}$ percentile. A similar multiple is formed for 1980 on the basis 1940s data.

Source: IPUMS (Ruggles and Sobek 1997). 
Table 4: Proportion of Home Owners with Mortgages

\begin{tabular}{cccccc}
\hline & 1900 & 1910 & 1920 & 1980 & 1990 \\
\hline $\begin{array}{c}\text { Northeast } \\
\text { Black }\end{array}$ & 0.50 & 0.51 & 0.66 & 0.84 & 0.84 \\
White & 0.45 & 0.48 & 0.56 & 0.76 & 0.78 \\
Midwest & & & & \\
Black & 0.38 & 0.50 & 0.48 & 0.86 & 0.82 \\
White & 0.41 & 0.42 & 0.48 & 0.77 & 0.77 \\
South & & & & & \\
Black & 0.25 & 0.28 & 0.33 & 0.74 & 0.76 \\
White & 0.16 & 0.23 & 0.30 & 0.77 & 0.75 \\
West & & & & & \\
Black & 0.25 & 0.30 & 0.54 & 0.87 & 0.91 \\
White & 0.23 & 0.29 & 0.45 & 0.85 & 0.85 \\
U.S. & & & & & \\
Black & 0.27 & 0.31 & 0.36 & 0.79 & 0.79 \\
White & 0.34 & 0.37 & 0.45 & 0.78 & 0.78 \\
\hline
\end{tabular}

Notes: Column figures give the proportion of home owners who have a mortgage as opposed to owning

"free and clear." Samples include men aged 20-64 who were household heads and were not in school.

Source: IPUMS (Ruggles and Sobek 1997). For 1990, we use the 1\% unweighted sample. 
Table 5: Decomposition of 1940 - 1960 Change in White - Black Ownership Gap

\begin{tabular}{|c|c|c|c|c|c|c|c|c|c|}
\hline & $\beta_{+}$ & $\left(\beta_{t+1}-\beta_{t}\right)$ & $\left(X_{w t}-X_{h t}\right)$ & $\begin{array}{c}\left(X_{w t+1}-\right. \\
\left.X_{b t+1}\right) \\
\end{array}$ & $\begin{array}{l}\text { First } \\
\text { Term } \\
\end{array}$ & $\begin{array}{c}\text { Second } \\
\text { Term } \\
\end{array}$ & $\begin{array}{l}\text { Third } \\
\text { Term } \\
\end{array}$ & $\begin{array}{c}\text { Fourth } \\
\text { Term } \\
\end{array}$ & Sum \\
\hline Age & 0.0269 & 0.0211 & 1.9260 & 0.6760 & -0.0337 & 0.0142 & & & \\
\hline $\mathrm{Age}^{2}$ & -0.0002 & -0.0003 & 155.7210 & 59.7270 & 0.0152 & -0.0167 & & & \\
\hline Education & 0.0241 & 0.0137 & 3.5978 & 2.8195 & -0.0187 & 0.0385 & & & \\
\hline Education $^{2}$ & -0.0010 & -0.0005 & 51.4472 & 48.8813 & 0.0027 & -0.0228 & & & \\
\hline Occupation & 0.0052 & 0.0007 & 7.9621 & 7.3047 & -0.0034 & 0.0048 & & & \\
\hline Farm & 0.1071 & -0.0949 & -0.1492 & -0.0006 & 0.0159 & 0.0001 & & & \\
\hline Family Size & 0.0059 & 0.0171 & -0.1959 & -0.5203 & -0.0019 & -0.0089 & & & \\
\hline Multifam & 0.0298 & -0.0091 & -0.0413 & -0.0388 & 0.0001 & 0.0004 & & & \\
\hline Married & 0.0254 & 0.1971 & 0.0261 & 0.0503 & 0.0006 & 0.0099 & & & \\
\hline Central City & -0.1374 & -0.0015 & 0.0263 & -0.2683 & 0.0405 & 0.0004 & & & \\
\hline Suburban & 0.0402 & 0.0353 & 0.1159 & 0.2325 & 0.0047 & 0.0082 & & & \\
\hline Midwest & 0.0888 & 0.0151 & 0.2198 & 0.0825 & -0.0122 & 0.0012 & & & \\
\hline South & 0.0706 & 0.0142 & -0.5109 & -0.2667 & 0.0172 & -0.0038 & & & \\
\hline West & 0.1491 & -0.0639 & 0.1087 & 0.0854 & -0.0035 & -0.0055 & & & \\
\hline Inter-Reg. Mig. & -0.0647 & -0.0030 & -0.0449 & -0.1810 & 0.0088 & 0.0005 & & & \\
\hline Foreign Born & 0.0073 & -0.0776 & 0.1443 & 0.0654 & -0.0006 & -0.0051 & & & \\
\hline
\end{tabular}

Contribution of

Each Term

$\begin{array}{lllll}0.0318 & 0.0157 & 0.0111 & -0.0085 & 0.0501\end{array}$

Notes: The decomposition is performed at the means of the distributions using the parameters from the white home ownership regression. The "first term" of equation 3 is $\left[\left(X_{w t+1}-X_{b t+1}\right)-\left(X_{w t}-X_{b t}\right)\right] \beta_{t}$. The "second term" is $\left(X_{w t+1}\right.$ $\left.X_{b t+1}\right)\left(\beta_{t+1}-\beta_{t}\right)$. The "third term" is $\left[\left(\delta_{\mathrm{wt}+1}-\delta_{\mathrm{bt}+1}\right)-\left(\delta_{\mathrm{wt}}-\delta_{\mathrm{bt}}\right)\right] \sigma_{\mathrm{wt}}$. The "fourth term" is $\left(\delta_{\mathrm{wt}+1}-\delta_{\mathrm{bt}+1}\right)\left(\sigma_{\mathrm{wt}+1}-\sigma_{\mathrm{wt}}\right)$.

See text for a discussion of each term's interpretation. Regressions coefficients are from linear probability models estimated for white men.

Source: IPUMS (Ruggles and Sobek 1997). 
Table 6: Decomposition of 1960 - 1980 Change in White - Black Ownership Gap

\begin{tabular}{|c|c|c|c|c|c|c|c|c|c|}
\hline & $\beta_{t}$ & $\left(\beta_{t+1}-\beta_{t}\right)$ & $\left(X_{w t}-X_{b t}\right)$ & $\begin{array}{c}\left(X_{w t+1}-\right. \\
\left.X_{b t+1}\right) \\
\end{array}$ & $\begin{array}{r}\text { First } \\
\text { Term } \\
\end{array}$ & $\begin{array}{c}\text { Second } \\
\text { Term } \\
\end{array}$ & $\begin{array}{l}\text { Third } \\
\text { Term } \\
\end{array}$ & $\begin{array}{c}\text { Fourth } \\
\text { Term } \\
\end{array}$ & Sum \\
\hline Age & 0.0480 & -0.0054 & 0.6760 & 0.7580 & 0.0039 & -0.0041 & & & \\
\hline $\mathrm{Age}^{2}$ & -0.0004 & 0.0001 & 59.7270 & 70.3440 & -0.0046 & 0.0037 & & & \\
\hline Education & 0.0377 & -0.0032 & 2.8195 & 1.4163 & -0.0529 & -0.0045 & & & \\
\hline Education $^{2}$ & -0.0015 & 0.0005 & 48.8813 & 32.6851 & 0.0244 & 0.0148 & & & \\
\hline Occupation & 0.0058 & -0.0017 & 7.3047 & 4.2649 & -0.0177 & -0.0071 & & & \\
\hline Farm & 0.0122 & -0.0229 & -0.0006 & 0.0278 & 0.0003 & -0.0006 & & & \\
\hline Family Size & 0.0229 & -0.0014 & -0.5203 & -0.2020 & 0.0073 & 0.0003 & & & \\
\hline Multifam & 0.0207 & -0.0365 & -0.0388 & -0.0248 & 0.0003 & 0.0009 & & & \\
\hline Married & 0.2225 & 0.0430 & 0.0503 & 0.1095 & 0.0132 & 0.0047 & & & \\
\hline Central City & -0.1389 & 0.0072 & -0.2683 & -0.3394 & 0.0099 & -0.0024 & & & \\
\hline Suburban & 0.0755 & -0.0869 & 0.2325 & 0.2260 & -0.0005 & -0.0196 & & & \\
\hline Midwest & 0.1039 & -0.0323 & 0.0825 & 0.0690 & -0.0014 & -0.0022 & & & \\
\hline South & 0.0848 & -0.0283 & -0.2667 & -0.1996 & 0.0057 & 0.0056 & & & \\
\hline West & 0.0853 & -0.0522 & 0.0854 & 0.1011 & 0.0013 & -0.0053 & & & \\
\hline Inter-Reg. Mig. & -0.0677 & 0.0109 & -0.1810 & -0.1043 & -0.0052 & -0.0011 & & & \\
\hline Foreign Born & -0.0702 & -0.0667 & 0.0654 & 0.0200 & 0.0032 & -0.0013 & & & \\
\hline
\end{tabular}

Contribution of

Each Term

$\begin{array}{lllll}-0.0128 & -0.0185 & -0.0405 & -0.0095 & -0.0813\end{array}$

Notes: The decomposition is performed at the means of the distributions using the parameters from the white home ownership regression. The "first term" of equation 3 is $\left[\left(X_{w t+1}-X_{b t+1}\right)-\left(X_{w t}-X_{b t}\right)\right] \beta_{t}$. The "second term" is $\left(X_{w t+1}\right.$ $\left.X_{b t+1}\right)\left(\beta_{t+1}-\beta_{t}\right)$. The "third term" is $\left[\left(\delta_{\mathrm{wt}+1}-\delta_{\mathrm{bt}+1}\right)-\left(\delta_{\mathrm{wt}}-\delta_{\mathrm{bt}}\right)\right] \sigma_{\mathrm{wt}}$. The "fourth term" is $\left(\delta_{\mathrm{wt}+1}-\delta_{\mathrm{bt}+1}\right)\left(\sigma_{\mathrm{wt}+1}-\sigma_{\mathrm{wt}}\right)$.

See text for a discussion of each term's interpretation. Regressions coefficients are from linear probability models estimated for white men.

Source: IPUMS (Ruggles and Sobek 1997). 
Table 7: Decomposition of 1960 - 1980 Change in Property Value Gap

\begin{tabular}{|c|c|c|c|c|c|c|c|c|c|c|}
\hline & \multicolumn{5}{|c|}{ Using White Coefficients } & \multicolumn{5}{|c|}{ Using Black Coefficients } \\
\hline & $\begin{array}{l}\text { First } \\
\text { Term }\end{array}$ & $\begin{array}{l}\text { Second } \\
\text { Term }\end{array}$ & $\begin{array}{l}\text { Third } \\
\text { Term }\end{array}$ & $\begin{array}{l}\text { Fourth } \\
\text { Term }\end{array}$ & Sum & $\begin{array}{l}\text { First } \\
\text { Term }\end{array}$ & $\begin{array}{l}\text { Second } \\
\text { Term }\end{array}$ & $\begin{array}{l}\text { Third } \\
\text { Term }\end{array}$ & $\begin{array}{l}\text { Fourth } \\
\text { Term }\end{array}$ & Sum \\
\hline Midwest & -0.004 & -0.005 & & & & -0.007 & -0.009 & & & \\
\hline South & 0.000 & 0.019 & & & & 0.004 & 0.000 & & & \\
\hline West & 0.003 & 0.018 & & & & 0.008 & 0.020 & & & \\
\hline Central City & -0.010 & -0.007 & & & & -0.016 & 0.037 & & & \\
\hline Suburb & -0.004 & 0.017 & & & & -0.005 & 0.027 & & & \\
\hline $\begin{array}{l}\text { House } \\
\text { Characteristics }\end{array}$ & -0.235 & -0.035 & & & & -0.180 & 0.007 & & & \\
\hline $\begin{array}{l}\text { Contribution } \\
\text { of each term }\end{array}$ & -0.249 & 0.007 & 0.067 & 0.063 & -0.112 & -0.197 & 0.082 & -0.024 & 0.026 & -0.112 \\
\hline Proportion of Change & 2.221 & -0.065 & -0.592 & -0.564 & 1.000 & 1.750 & -0.728 & 0.210 & -0.232 & 1.000 \\
\hline
\end{tabular}

Notes: The decomposition is carried out at the sample means. The property value gap is log white value log black value, and so positive entries in the table represent a widening of the gap whereas negative entries represent a narrowing of the gap. The sample includes male household heads, age 20-64, not in school, who live in owner-occupied housing with estimated property values available. See note to Table 3 for description of treatment of topcodes. House characteristics include: the number of rooms, the number of bathrooms, the type of heating system, and the building's age. The first term reflects change in relative characteristics from 1960 to 1980 . The second term reflects change in coefficients. The third term reflects change in the standardized residuals. The fourth term reflects change in the residual variance.

Source: IPUMS (Ruggles and Sobek 1997). 
Table 8: Segregation, Home Ownership, and Property Values

\begin{tabular}{|c|c|c|c|c|}
\hline Panel A: Ownership & 1940 Ownership & 1940 Ownership & 1980 Ownership & 1980 Ownership \\
\hline \multirow[t]{2}{*}{ Black } & -0.2573 & -0.2487 & -0.1324 & -0.0958 \\
\hline & $(0.0469)$ & $(0.0479)$ & $(0.0174)$ & $(0.0175)$ \\
\hline \multirow[t]{2}{*}{ Black*Segregation } & 0.2067 & 0.1586 & 0.0944 & -0.0092 \\
\hline & $(0.0619)$ & $(0.0631)$ & $(0.0241)$ & $(0.0242)$ \\
\hline \multirow[t]{2}{*}{ Central City } & -0.1949 & ----- & -0.1057 & ----- \\
\hline & $(0.0031)$ & & $(0.0018)$ & \\
\hline Observations & 98587 & 98587 & 261636 & 261636 \\
\hline Adjusted $\mathrm{R}^{2}$ & 0.18 & 0.15 & 0.30 & 0.29 \\
\hline Panel B: Log Value & 1940 Value & 1940 Value & 1980 Value & 1980 Value \\
\hline \multirow[t]{2}{*}{ Black } & -1.3449 & -1.3402 & 0.1978 & 0.2103 \\
\hline & $(0.2088)$ & $(0.2089)$ & $(0.0298)$ & $(0.0298)$ \\
\hline \multirow[t]{2}{*}{ Black*Segregation } & 0.7725 & 0.7726 & -0.7368 & -0.7805 \\
\hline & $(0.2786)$ & $(2788)$ & $(0.0405)$ & $(0.0405)$ \\
\hline \multirow[t]{2}{*}{ Central City } & 0.0652 & ---- & -0.0576 & ---- \\
\hline & $(0.0091)$ & & $(0.0026)$ & \\
\hline Observations & 36312 & 36312 & 156468 & 156468 \\
\hline Adjusted $\mathrm{R}^{2}$ & 0.09 & 0.09 & 0.57 & 0.57 \\
\hline
\end{tabular}

Notes: Segregation is measured with a dissimilarity index which ranges from 0 to 1 and is based on census tracts. The weighted average in 1940 was 0.78 (standard deviation of 0.09 ) and in 1940 was 0.70 (standard deviation of 0.11). Segregation measures are available for a larger number of cities in 1980 than in 1940. Regressions for ownership include controls for age, age squared, education, education squared, occupation, marital status, family size, farm, multiple families in household, and migrant status. Regressions for value in 1980 include controls for the number of rooms, building age, number of 
bathrooms, heating system. These variables are not available for 1940.

Sources: Ownership, value, and household variables are taken from the IPUMS (Ruggles and Sobek 1997).

Segregation measures are from Cutler, Glaeser, and Vigdor (1999). 
Figure 1:

Home Ownership Rates, 1900 - 1990

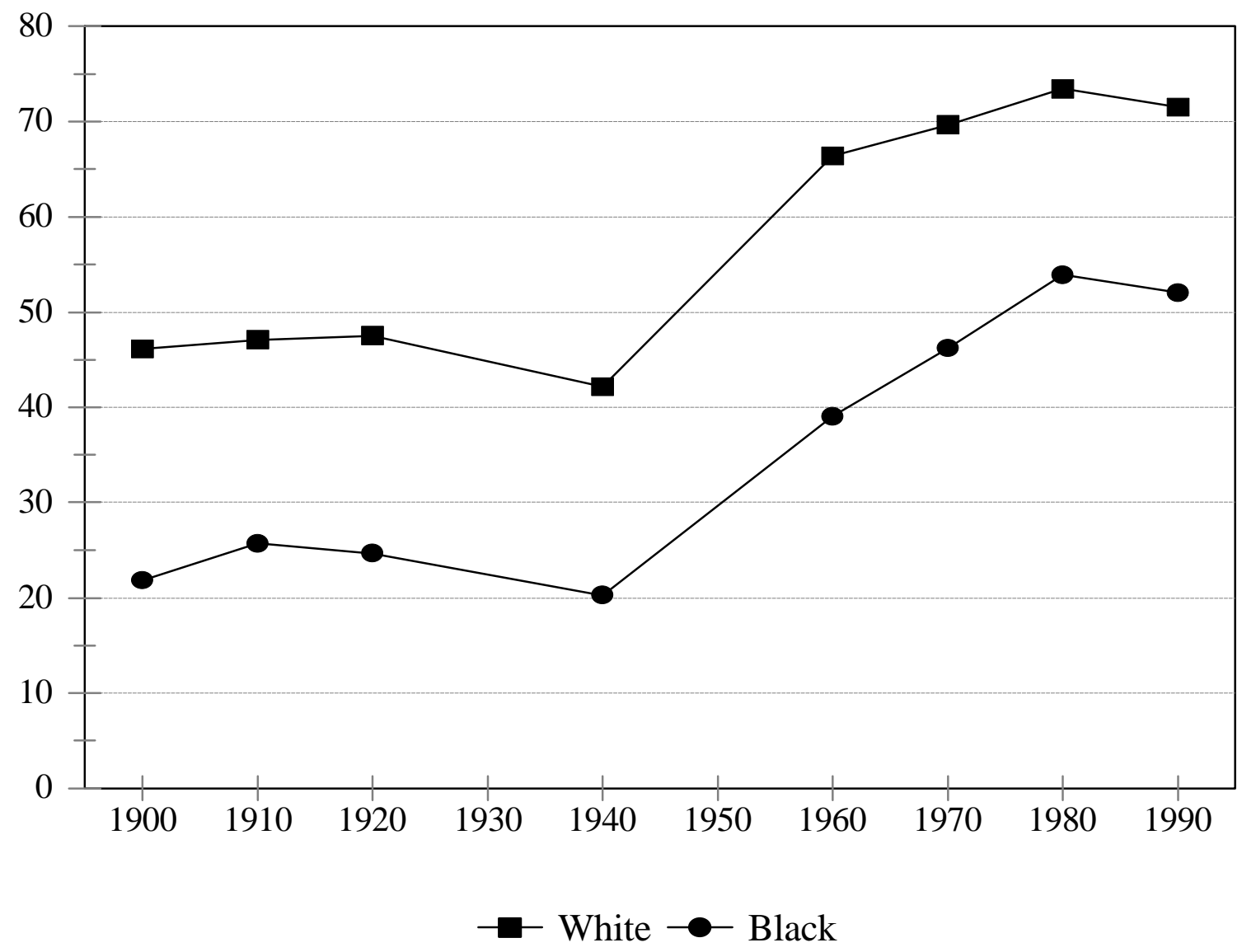

Note: The figure graphs home ownership rates for black and white male household heads, ages 20 to 64 , who were not in school.

Source: IPUMS (Ruggles and Sobek 1997). 
Figure 2:

White-Black Home Ownership Gap

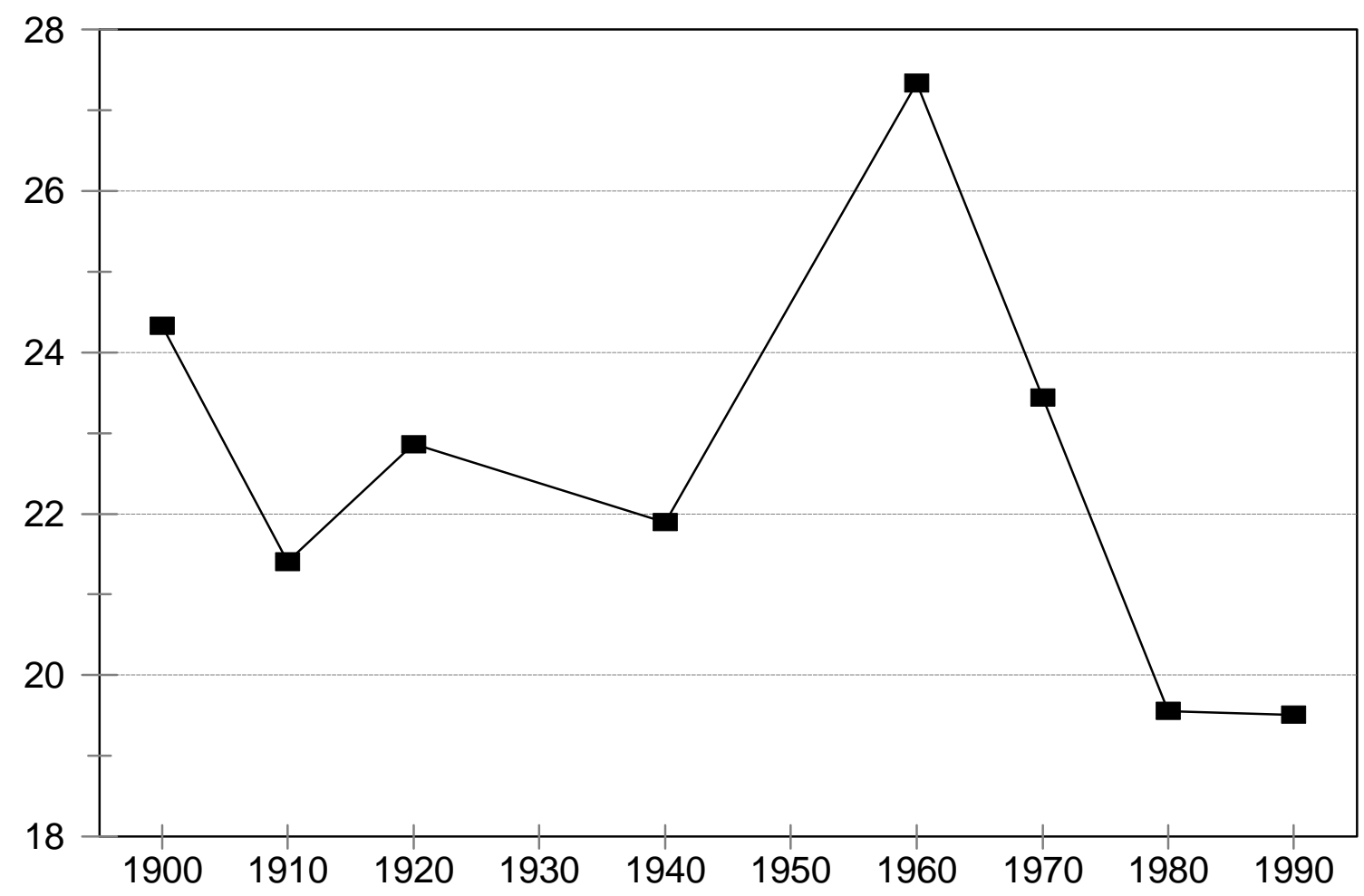

Notes: The figure graphs the absolute difference in the white and black home ownership rates for white and black male household heads, ages 20 to 64, who were not in school.

Source: IPUMS (Ruggles and Sobek 1997). 